\title{
Development, quality evaluation and storage study of chicken meat pickle
}

\author{
Sunil Rajbanshi ${ }^{1}$, Bhaskar M. Adhikari ${ }^{1} *$ and Dilip Subba ${ }^{2}$ \\ 1 Department of Food Technology, National College of Food Science and Technology, \\ Kathmandu, Nepal
}

2 Central Campus of Technology, Tribhuvan University, Nepal

*Corresponding author.

Bhaskar Mani Adhikari

TEL: +977-9841413448;

FAX: +977-1-4428724;

E-MAIL: vaskarmani@gmail.com; bm.adhikari@ nist.edu.np

\section{Abstract}

A study was undertaken to develop shelf stable intermediate moisture type chicken meat pickle and evaluate its quality and storage stability. Pre-cooked and fried lean minced chicken meat was mixed with salt, spices and vinegar and packed air tight in glass jar. The product had appreciable sensory quality and low total microbial, yeast and mould counts. Salmonella, Staphylococci and E. coli were found absent in the product. Microbial count and peroxide value lay within the acceptable levels for sixty days.

\section{Introduction}

The name meat pickle is given to the meat based condiment made up of meat, spices, salt, vegetable oil and with or without acetic acid (Sidhu et al., 1995). It is an unfermented, spicy ready to eat meat preparation generally stable for several weeks due to low moisture content (Maiti et al., 2009). In the orient, especially in countries like India, Nepal and some countries of Far East pickle type of food is well known for its appetite enhancing property and the property to aid in digestion of food by stimulating the flow of gastric juice. In place of skeletal muscle different viscera of animal and poultry can also be used for the preparation of meat pickle. Meat pickle is also good alternative of meat in times of its scarcity. Preparation of different types of meat pickle has been reported (Pal, 1990; Pal and Agnihotri, 1994; Sachdev et al., 1994; Puttarajappa et al.,1996; Shukla and Srivastava, 1999; Sen and Karim, 2003; Das et al., 2007; Gadekar et al., 2010; Kanagaraju and Subramanian, 2012; Das et al., 
2013). This work was aimed to develop a shelf stable intermediate moisture type chicken meat pickle.

\section{Materials and Methods}

Freshly prepared dressed broiler chicken was procured from the local market of Kathmandu. Meat was separated from the carcass and trimmed to remove adhering fatty tissues. Meat was weighed, cut into thump size pieces and cooked in boiling water (1:1) to dryness. The cooked meat pieces were minced in manual type meat grinder through a $3 \mathrm{~mm}$ plate. The minced meat was fried in little mustard oil in frying pan at $175 \pm 5^{\circ} \mathrm{C}$ to golden brown colour. The excess oil was drained off. Type of spices used, their preliminary preparation like peeling and grinding, and the amounts of prepared spices taken followed the method of Kanagaraju and Subramanian (2012) and Das et al., (2013) as shown in recipe table (Table 1).

Table 1: Spices used in meat pickle

\begin{tabular}{ll}
\hline Ingredients & amount (g/100g lean meat) \\
\hline Cumin & 1 \\
Coriander & 0.55 \\
Turmeric & 1 \\
Mustard seed & 1 \\
Chili powder & 3 \\
Black pepper & 0.12 \\
Cardamom & 0.17 \\
Fenugreek & 0.5 \\
Clove & 0.11 \\
Cinnamon & 0.17 \\
Asafetida & 0.5 \\
Chicken masala & 1 \\
Onion & 28 \\
Garlic & 5 \\
Ginger & 5 \\
MSG & 0.05 \\
Vinegar (ml) & 10 \\
Salt & 5 \\
\hline Source: Kanagara & \\
\hline
\end{tabular}

Source: Kanagaraju and Subramanian (2012), Das et al., (2013) 
The spices were mixed and fried in the drain oil. The spices, salt, MSG and vinegar were mixed with meat and the pickle was filled in clean dry glass jar up to the neck. This was topped with mustard oil which was heated to $175^{\circ} \mathrm{C}$ and cooled to room temperature a short while ago. Samples for analysis from the ready pickle were drawn. The bottle filled with the meat pickle was capped air-tight and stored in a dry place at room temperature for investigation. Chemical composition, sensory quality, microbiological quality, acid value and peroxide value were investigated at fifteen day intervals up to two months. Moisture, crude protein, crude fat, salt, peroxide value and acid value were determined according to AOAC (2005). Microbiological analysis (Total plate count, coliform count, Staphylococcus detection, Salmonella detection, Yeast and mold count) was carried out according to APHA (1984). Sensory test was done by 9-point hedonic rating test in the participation of twenty semi trained panelists comprising of faculties and undergraduate students of National College of Food Science and Technology, Kathmandu. Statistical analysis was performed using Microsoft Excel (2003/2007), GENSTAT Discovery Edition 4.

\section{Results and Discussion}

Cooking denatures meat proteins and decreases water holding capacity of meat. As a consequence meat loses water. Also by frying water is removed from meat. Cooking improves palatability of meat and also causes destruction of microorganisms present in meat. In meat products spices are added primarily to enhance the flavor. Some spices are known to exert antibacterial and antioxidant effects. The moisture content and other compositional parameters of the meat pickle are shown in Table 2.

Table 2: Chemical composition of chicken meat pickle

\begin{tabular}{ll}
\hline Moisture & $24.87 \pm 0.82 \%$ \\
Protein & $20.91 \pm 0.3 \%$ \\
Fat & $50.03 \pm 0.21 \%$ \\
Salt & $3.51 \pm 0.29 \%$ \\
\hline
\end{tabular}

This composition was similar to that of shelf stable duck meat pickle prepared by Kanagaraju and Subramanian (2012). The meat pickle had appreciable overall sensory quality rated as "moderately liked" in hedonic rating scale (Figure 1). There was no significant ( $p>0.05$ ) change in the sensory quality of meat pickles during storage. This finding is in close 
agreement with that of Shukla and Srivastava (1999), Shrestha (2001) and Kanagaraju and Subramanian (2012).

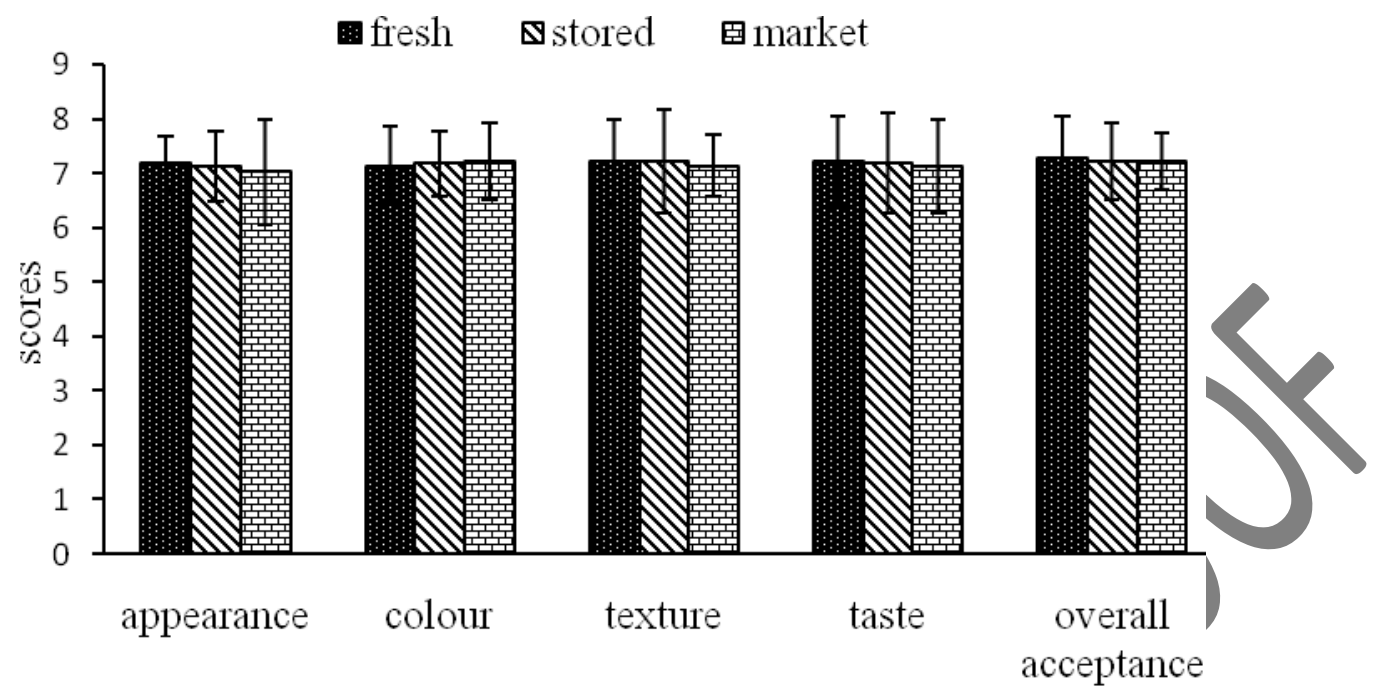

parameter

Figure 1. Sensory test scores for chicken meat pickle

The total plate count was low (Table 3 ) which could be due to microbial destruction by cooking meat in boiling water and pan-frying of meat. The bactericidal action of acetic acid is also long known.

Table 3. Microbiological quality of chicken meat pickle

\begin{tabular}{llllll}
\hline Parameters & \multicolumn{5}{l}{ Storage period (day) } \\
\cline { 2 - 6 } & 0 & 15 & 30 & 45 & 60 \\
\hline Total plate count $(\log \mathrm{cfu} / \mathrm{g})$ & $1.43 \pm 0.48$ & $1.83 \pm 0.76$ & $2.34 \pm 0.23$ & $2.47 \pm 0.93$ & $2.79 \pm 0.17$ \\
Yeast and moulds $(\log \mathrm{cfu} / \mathrm{g})$ & $0.8 \pm 0.2$ & $1 \pm 0.53$ & $1.1 \pm 0.61$ & $1.4 \pm 0.4$ & $1.83 \pm 0.09$ \\
Coliform & $\mathrm{ND}$ & $\mathrm{ND}$ & $\mathrm{ND}$ & $\mathrm{ND}$ & $\mathrm{ND}$ \\
Staphylococcus spp. & $\mathrm{ND}$ & $\mathrm{ND}$ & $\mathrm{ND}$ & $\mathrm{ND}$ & $\mathrm{ND}$ \\
Salmonella spp. & $\mathrm{ND}$ & $\mathrm{ND}$ & $\mathrm{ND}$ & $\mathrm{ND}$ & $\mathrm{ND}$ \\
\hline
\end{tabular}

ND: Not detected

The commercial product vinegar is made from acetic acid. The total plate count did not change significantly during storage for two months. Kanagaraju and Subramanian (2012) have also similar observations. The good shelf stability is attributed to low moisture content 
(24.8\%) and low $\mathrm{pH}$. Originally the $\mathrm{pH}$ value of the chicken pickle was 4.65 which increased somewhat, that is to 4.75 during storage (Table 4).

Table 4. Chemical characteristics of pickle

\begin{tabular}{cccccc}
\hline Parameters & \multicolumn{5}{c}{ Storage period (day) } \\
& 0 & 15 & 30 & 45 & 60 \\
\hline $\mathrm{pH}$ & $4.65 \pm 0.04$ & $4.68 \pm 0.07$ & $4.72 \pm 0.06$ & $4.73 \pm 0.06$ & $4.76 \pm 0.05$ \\
$\begin{array}{c}\text { Peroxide value } \\
(\mathrm{mEq} / \mathrm{kg})\end{array}$ & $2.45 \pm 0.39$ & $3.81 \pm 0.24$ & $5.14 \pm 0.28$ & $7.85 \pm 0.17$ & $9.91 \pm 0.12$ \\
& & & & & \\
\hline
\end{tabular}

Such trend is observed also by Das et al., (2007), Maiti et al.,(2009) and Das et al., (2013). Furthermore, salt and mustard oil should have contributed to the inhibition of microbial growth. Mustard oil is commonly used in Nepalese cuisine as cooking oil especially for cooking meat. There is a Nepalese indigenous raw meat preparation (eaten raw) called Kachila in which hot mustard oil is added (Shrestha and Rao, 2007). Mustard oil imparts pleasant pungent flavor to meat (McGorrin, 2011). Also, it contains an active principle, allylisothiocyanate reported as antibacterial compound (Luciano et al., 2008; Dias et al., 2014). The microbial load was lower than $4 \log \mathrm{cfu} / \mathrm{g}$ suggesting it to be safe for eating. There are different types of pathogenic bacteria associated with meat. Coliform, salmonella and staphylococci have public health importance. These bacteria were not found in the meat pickle. They must have been destroyed by the cooking processes (cooking in water and pan frying). Cooking is capable of destroying other common meat borne pathogens like E. coli, B. cereus and $\mathrm{Cl}$.Perfringens. Small and insignificant change in yeast and mould counts during storage was observed. The pickle was a high fat product (50\% fat) and so oxidative rancidity was expectable. The peroxide value $(\mathrm{PV})$ of pickle increased $(\mathrm{p}<0.05)$ during storage from 2.45 to $9.91 \mathrm{mEqO}_{2} / \mathrm{kg}$ (Table 4 ) however this value is within the acceptable limit as per Codex standard $\left(10 \mathrm{mEqO}_{2} / \mathrm{Kg}\right)$.

\section{Conclusions}

This work shows that selecting a process that combines cooking of meat and addition of acetic acid, salt and spices to the pre-cooked low moisture meat makes it possible to prepare chicken meat pickle of appreciable sensory quality, microbiological safety and appreciable 
storage life. As rancidity limits the storage life of this type of high fat product solving this problem will be of scientific and commercial value.

\section{References}

AOAC (2005). Official Methods of Analysis, $18^{\text {th }}$ edition, Association of Official Analytical Chemists, Washington, DC

APHA (1984). Compendium of Methods for the Microbiological Examination of Foods, 2nd edition, American Public Health Association, Washington, DC

Das, A.K., Sharma, A.B. and Singh, N.P. (2007). Quality and Storage Stability of Low Acid Goat Pickle. American Journal of Food Technology.2(6):550-554. doi: 10.3923/ajft.2007.550.554

Das, A., Ranjan Nath, D., Hazarika, M. and Laskar, K.S. (2013). Studies on Certain Quality Attributes of Meat Pickle Prepared from Spent Chicken. Veterinary World. 6(3):156-158. doi: 110.5455/vetworld.2013.156-158

Dias, C., Aires, A. and Saavedra, M. J. (2014) Antimicrobial Activity of Isothiocyanates from Cruciferous Plants against Methicillin-Resistant Staphylococcus aureus (MRSA). International Journal of Molecular Sciences, 15, 19552-19561; doi: 10.3390/ijms151119552

Gadekar, Y.P., Kokane, R.D., Suradkar, U.S., Thomas, R., Das, A.K. and Anjaneyulu, A.S. R. (2010). Shelf Stable Meat Pickles- a Review. International Food Research Journal, 17: 221-227.

Kanagaraju, P. and Subramanian, A. (2012). Preparation of Spent Duck Meat Pickel and its Storage Studies at Room Temprature. American Journal of Food Technology, 7(1): 29-33. doi: $10.3923 / a j f t .2012 .29 .33$

Luciano, FB. Hosseinian, F. S., Beta, T. and Holley, R. A. (2008). Effect of free-SH containing compounds on allyl isothiocyanate antimicrobial activity against Escherichia coli 0157:H7. Journal of Food Science. 73(5):M214-20. doi: 10.1111/j.17503841.2008.00762.x.

Maiti, A.K., Ahlawat, S.S. and Khanna, N. (2009). Studies on Development of Tenderized Chicken Gizzard and Goat Heart Pickles. Indian Journal of Animal Research. 43(4):255258.

McGorrin R. J. (2011). The Significance of Volatile Sulfur Compounds in Food Flavors An Overview. In: Volatile Sulfur Compounds in Food; (Qian, M. et al. Ed) ACS Symposium Series; American Chemical Society: Washington, DC. doi: 10.1021/bk-2011-1068.ch001 
Pal, U.K. (1990). Studies on preparation, packaging, preservation of pork pickle. PhD Thesis IVRI, Deemed University, Izatnagar, India.

Pal, U. K. and Agnihotri, M. K. (1994). Storage Stability of Chevon Pickle at Room Temperature. Journal of Applied Animal Research, 5. 89-93.

Puttarajappa, P., Nair, K. K. S and Rao, D. N. (1996). Studies on Shelf Stable Chicken. Journal of Food Science and Technology, 33, 501-508.

Sachdev, A. K., Gopi, R. and Verma, S. S. (1994). Storage Stability of Chicken Gizzard Pickle. Indian Journal of Poultry Science, 27, 217-223.

Sen, A. R. and Karim, S. A. (2003). Storage Stability of Rabbit Pickle at Room Temperature. Journal of Food Science and Technology, 40:197-200.

Shrestha, H. and Rao, E. R. (2007). Traditional Foods and Beverages of Newari communityA brief review. Journal of Food Science and Technology Nepal, 3:1-10.

Shrestha, P. (2001). Development, Quality Evaluation and Storage Study of Buffalo Meat Pickle. Unpublished B. Tech. (Food) Dissertation. Tribhuvan University, Nepal.

Shukla, P. K. and Srivastava, R. K. (1999). Effect of an Antioxidant on Shelf life of Chicken Pickle. Indian Journal of Poultry Science, 34:405-408.

Sidhu, J. S., Puttarajappa, P. and Kumar, K. R. (1995). Studies on Keeping Quality of Pickled Chicken in Flexible Pouches. Journal of Food Science and Technology, 32(5):377-380. 